\title{
SIAPAKAH DIA: SANG PENASIHAT AJAIB, ALLAH YANG PERKASA, BAPA YANG KEKAL DAN RAJA DAMAI? STUDI TERHADAP MAKNA TEKS YESAYA 8:23-9:6
}

\author{
Marde Christian Stenly Mawikere ${ }^{1)^{*}}$ \\ ${ }^{1)}$ Mahasiswa Program Doktor Prodi Teologi Sekolah Tinggi Theologia Jaffray \\ *)Penulis korespondensi: mardestenly@gmail.com
}

\begin{abstract}
Abstrak
Artikel ini menyoroti mengenai siapakah sosok Sang Penasihat Ajaib, Allah Yang Perkasa, Bapa Yang Kekal dan Raja Damai bagi bangsa Israel sebagaimana yang ditegaskan oleh Nabi Yesaya dalam situasi kegentingan raja dan rakyat Israel Selatan/Yehuda dalam konflik dengan Imperium kerajaan Asyur. Studi ini dibangun dengan pendekatan kritik historis yang memberi gambaran mengenai situasi sosial politik bangsa Israel yang dalam tekanan dan krisis menghadapi raja-raja Asyur yang silih berganti menantang umat Allah tersebut. Pada situasi tersebut, Allah mengutus nabi Yesaya untuk menyampaikan firman Tuhan mengenai pentingnya mengandalkan Tuhan dan perlindungan-Nya yang kekal ketimbang percaya kepada manusia yang kekuatan-Nya terbatas dan temporer. Di tengah-tengah krisis tersebut, Allah (Yahweh) menyatakan diri sebagai Yang Maha Kudus, Allah Israel yang trancendent sekaligus immanent dengan menghadirkan diri-Nya dalam gaya bahasa "antropomorfisme" sebagai Penasihat Ajaib, Allah Yang Perkasa, Bapa Yang Kekal dan Raja Damai bagi bangsa Israel. Atribut Allah yang demikian memiliki makna bagi bangsa Israel bahwa Dia adalah pembebas dan penyelamat mereka. Hal ini juga merupakan jejak bagi inkarnasi-Nya kelak yang digenapi dalam Perjanjian Baru. Sehingga dalam Kitab Yesaya, dapat ditemukan kekayaan akar-akar inkarnasi Yesus Kristus, yakni Allah yang menjadi manusia.
\end{abstract}

Kata-kata kunci: Allah, manusia, pembebasan, keselamatan, pemberitaan

This article highlights who was the figure called Wonderful Counselor, Mighty God, Eternal Father, and the Prince of Peace to the nation of Israel as delineated by the prophet Isaiah in the critical situation the king and people of Southern Israel/Judah faced in their conflict with the Assyrian Empire. This study utilizes the historical-critical approach which gives an overview of the socialpolitical situation of the nation of Israel which was experiencing pressure and crisis from the kings of Assyria who alternated challenging the people of God. In this situation God commissioned the prophet Isaiah to deliver the word of God concerning the importance of depending on the Lord and his eternal protection rather than trusting in man and his limited and temporary strength. In the midst of this crisis, God (Yahweh) revealed himself as the Holy One, the 
God of Israel who is transcendent as well as immanent, who presents himself in anthropomorphic language as the Wonderful Counselor, Mighty God, Everlasting Father, and Prince of Peace for the nation of Israel.These attributes of God thus have a meaning for the nation of Israel that God is their deliverer and rescuer. These descriptions also represent a trail showing his coming Incarnation that would be fulfilled in the New Testament. Therefore, in the book of Isaiah can be found the rich roots of the Incarnation of Jesus Christ, that is God who became human.

Keywords: God, human, liberation, salvation, proclamation

\section{Pendahuluan}

Teks Yesaya 8:23-9:6 menjadi berita sukacita bagi setiap orang Kristen, karena sering dihubungkan dengan pribadi Tuhan Yesus Kristus dan karya pembebasan dan keselamatan yang dilakukan Tuhan Yesus Kristus bagi umat manusia. Akan tetapi apabila makna teks tersebut hanya ditinjau dari Perjanjian Baru, khususnya dalam Injil Matius 4:1516; Lukas 1:32-33, 79, lalu apa maknanya bagi pembaca mula-mula Kitab Yesaya, secara khusus bagi bangsa Israel yang pada saat itu telah terpecah dalam dua kerajaan; Israel Utara dan Israel Selatan/Yehuda. Siapakah sosok yang dimaksudkan dengan Sang Penasihat Ajaib, Allah Yang Perkasa, Bapa Yang Kekal dan Raja Damai bagi bangsa Israel pada saat itu? Lalu apakah tepat atau kurang tepat apabila langsung ditarik kepada Tuhan Yesus Kristus yang kehadiran-Nya baru sekitar 700 tahun kemudian?

Studi ini mencoba meneliti Siapakah sosok tersebut bagi pembaca mula-mula serta apakah dapat dikaitkan dengan kepercayaan orang Kristen sejak masa Perjanjian Baru sampai kini yang menerapkan nubuat tersebut kepada Tuhan Yesus Kristus. Studi ini dibangun berdasarkan kritik historis (historical critism) terhadap konteks historis Kitab Yesaya serta dilengkapi oleh pendekatan analisa respons pembaca (reader response analysis). Studi ini diawali dengan tinjauan singkat terhadap konteks historis-biblika tentang Nabi Yesaya dan konteks teologisbiblika tentang nubuat Yesaya yang akan memberikan gambaran mengenai peran nabi dalam situasi sosial politik Israel serta gambaran mengenai sosok yang dinantikan. Kemudian dilanjutkan dengan eksposisi singkat ${ }^{1}$ makna teks Yesaya 8:23-9:6 yang akan menuntun untuk memahami sedikit mengenai atribut sosok yang dimaksud. Setelah itu akan dipaparkan mengenai siapakah sosok yang dimaksud

\footnotetext{
${ }^{1}$ Penulis tidak melakukan kritik teks/kritik naskah terhadap teks Yesaya 8:23-9:6 karena menurut penulis pendekatan kritik historis yang akan dapat memberikan gambaran mengenai permasalahan yang diangkat dalam tulisan ini.
} 
berdasarkan pendapat beberapa pakar maupun pendapat penulis yang akan diakhiri dengan penutup sebagai kesimpulan.

Konteks Historis-Biblika Yesaya dan Kenabiannya ${ }^{2}$

\section{Yesaya dan Pelayanan Kenabiannya}

Pemberitaan firman Tuhan yang diberitakan oleh para nabi tidak dapat dimengerti apabila terpisah dari konteks sejarah yaitu latar belakang kerohanian dan sosial politik pada zaman mereka. Yesaya bin Amos adalah nabi yang melayani dan bernubuat terhadap Kerajaan Yehuda/Israel Selatan pada zaman pemerintahan raja Uzia (Azarya; 783742 SM), Yotam (742-735 SM), Ahas (735-715 SM), dan Hizkia (715-687 SM). ${ }^{3}$ Pelayanan Yesaya sebagai Nabi diawali dengan pernyataan mengenai kematian raja Uzia (742 SM) yang merupakan akhir dari zaman kemakmuran dan kedamaian yang relatif di Yehuda dengan munculnya ancaman baru dari Kerajaan Asyur. Pelayanan kenabian Yesaya setelah tercatat dalam Yesaya 6 melalui pengalaman penglihatan di Bait Suci di kota Yerusalem, yang mana Yesaya "melihat Tuhan duduk di atas takhta yang tinggi dan menjulang" (ay. 1) dan ia "melihat Sang Raja" (ay. 5).

Adapun melalui penglihatan Yesaya di Bait Suci, maka panggilan kenabian Yesaya memiliki misi untuk menyampaikan firman Tuhan kepada bangsa Israel yang keras kepala sampai nanti kerajaan Yehuda hancur dan tunas kudus muncul kembali (Yes. 6:9-11). Misi pelayanan nabi Yesaya tersebut bukanlah sesuatu yang mudah untuk dilakukan sebab sekalipun ia dipanggil untuk menyampaikan firman Tuhan kepada bangsa Israel dengan terus menerus namun mereka tidak mau mendengarkan firman Tuhan tersebut (Yes. 6:10). Sekalipun demikian, Yesaya tidak boleh putus asa dan menyerah melainkan harus tetap memperingatkan bangsa Israel akan kejahatan dan hukuman yang menanti mereka apabila mereka tidak bertobat (Yes. 1:16-20). Yesaya diutus Tuhan untuk mengingatkan bangsa Israel akan kekudusan Tuhan, Allah mereka yang mengatasi kekuasaan segala makhluk (Yes. 6:3). Hal ini nampak dengan jelas saat Yesaya berulang kali menegaskan bahwa "TUHAN adalah Yang Maha Kudus, Allah Israel" (Yes. 1:4; 5:16,19,24; 10:20; 30:15; 31:1). Diharapkan supaya orang Israel menyadari kekudusan Tuhan dan mereka bertobat dengan sikap dan tindakan hidup kudus. Karena mereka adalah umat Tuhan, milik Tuhan maka

${ }^{2}$ Konteks Historis Biblika ini tidak bermaksud mengulas keseluruhan mengenai konteks historis Kitab Yesaya termasuk tidak membahas diskusi mengenai Proto, Deutro dan Trito-Yesaya maupun kesatuan Kitab Yesaya, melainkan dibatasi kepada tinjauan yang akan mengantar kepada pemahaman terhadap konteks yang menjadi latar belakang dari teks Yesaya 8:23-9:6.

${ }^{3}$ Hendrik P. Njolah. Mengenal Nabi Yesaya, Nabi Yeremia, Nabi Yehezkiel dan Nabi Amos (Yogyakarta: Yayasan Pustaka Nusatama, 2013), 19. 
mereka harus hidup sesuai dengan eksistensi mereka. Menurut Yesaya, tidak berguna apabila mereka rajin mengadakan ritual, namun tidak berhenti melakukan kejahatan (Yes. 1:10-15).

Hal penting lain berkaitan dengan pelayanannya adalah teguran Yesaya terhadap bangsa Israel yang lebih mengandalkan manusia ketimbang Tuhan. Mereka harus percaya penuh kepada perlindungan Tuhan serta tidak boleh takut dan gentar terhadap segala bahaya yang mengancam (Yes. 7:4-9; 30:15). Ditegaskan oleh Yesaya bahwa bangsa Israel harus lebih percaya kepada kekuatan Tuhan daripada percaya kepada kekuatan manusia (Yes. 31:1-9).

\section{Konteks Sosial Politik Zaman Pelayanan Yesaya}

Sekalipun Nabi Yesaya terlibat dengan empat raja Yehuda selama masa pemerintahan mereka, namun situasi sosial politik pemerintahan raja Ahas yang menonjol pada panggilan pelayanannya. Raja Ahas melakukan apa yang tidak benar di mata TUHAN (2 Raj. 16:2). "Ia membuat patung-patung tuangan untuk para baal, membakar korban di Lebak Ben-Hinom dan anak-anaknya sebagai korban dalam api." Akibat kelakuan dari raja Ahas, Tuhan menyerahkan Ahas dan seluruh negerinya ke dalam tangan raja orang Aram (2 Taw. 28:3-5).

Pada tahun 734 SM raja Asyur Tiglat Pileser III mengadakan ekspedisi dan ekspansi militer ke bagian barat Timur Tengah dan mengalahkan kerajaan-kerajaan yang terletak di pantai Laut Tengah seperti Tirus dan Filistea sampai ke kota Gaza dan wadi di Mesir. Ini berarti bahwa kerajaan-kerajaan Aram, Israel, Yehuda, Fenisia dan Mesir terancam keberadaannya, bahkan pada tahun 734 SM kerajaan Asyur melakukan invasi ke Israel Utara dengan menduduki daerah-daerah utara Israel yang disebut "wilayah bangsa-bangsa lain," yaitu Galilea (Yes. 8:23). Menyadari akan ancaman tersebut maka pada tahun 735 SM, Rezin, raja Aram dan Pekah, raja Israel bersepakat memaksa Ahas, raja Yehuda untuk berkoalisi untuk konflik melawan Asyur. Namun, Ahas yang belum lama menjadi raja menggantikan ayahnya raja Yotam menolak bergabung. Kemudian kedua raja itu mengumumkan perang melawan Yehuda dengan mengepung kota Yerusalem dengan maksud menggulingkan raja Ahas (2 Raj. 16:5). Perang tersebut dinamakan perang Suriah-Efraim (734-733). ${ }^{4}$

Raja Ahas tidak berdiam diri, namun meminta bantuan raja Asyur Tiglat Pileser III sekalipun Ahas ditegur oleh nabi Yesaya. Permintaan koalisi Yehuda dan Asyur ini diterima oleh raja Asyur Tiglat Pileser III karena berarti kerajaan Yehuda akan berada di bawah imperium Asyur

\footnotetext{
${ }^{4}$ Berthold Anton Pareira. Kritik Sosial Politik Nabi Yesaya (Malang: Penerbit Dioma, 2006), 37.
} 
tanpa harus perang, apalagi Asyur memang sudah punya rencana untuk invasi ke Samaria dan Damsyik. Kemudian raja Asyur Tiglat Pileser III datang menyerang Israel Utara dan menguasai tanah Galilea. Selanjutnya ia invasi ke tanah Palestina dari sepanjang pantai Israel Utara di seberang sungai Yordan (tanah Gilead) yang dilanjutkan dengan invasi ke tanah Aram dengan ibukotanya Damsyik pada tahun $732 \mathrm{SM}^{5}$ Ketergantungan raja Yehuda Ahas kepada manusia (raja Asyur Tiglat Pileser III) dan bukan kepada Tuhan yang menjadi latar belakang teguran dan nubuat nabi Yesaya yang tersebar dalam teks-teks Kitab Yesaya.

Pada tahun 726 SM raja Asyur Tiglat Pileser III mangkat dan digantikan oleh raja Salmanesser V. Sementara kerajaan Israel Utara tetap memberontak melawan kerajaan Asyur. Akhirnya pada tahun 721 SM setelah tiga tahun dikepung, seluruh kota Samaria jatuh dan dikuasai oleh kerajaan Asyur. ${ }^{6}$ Kerajaan Israel Utara dihapus oleh Raja Sargon II dan sebagian besar penduduknya dibuang ke Asyur. Menurut Nabi Yesaya, runtuhnya kerajaan Israel disebabkan karena keangkuhan dan nafsu kekuasaan para pemimpinnya serta sikap permusuhannya terhadap saudara mereka kerajaan Israel Selatan-Yehuda (Yes. 28:1-4).

Adapun kerajaan Israel Selatan-Yehuda sementara waktu masih bertahan karena berkoalisi dan mengalah kepada Asyur. Namun lama kelamaan kerajaan Yehuda, di bawah pemerintahan raja Hizkia mulai menjajagi kemungkinan untuk berkoalisi dan memberontak melawan Asyur. Kerajaan Filistea mengutus suatu delegasi ke Yerusalem untuk mengajak Yehuda masuk ke dalam koalisi melawan Asyur. Mendengar rencana itu, Yesaya tampil memperingatkan para penguasa Yehuda supaya tidak ikut serta dalam koalisi ini, tetapi mencari keselamatannya dalam Tuhan yang telah mendirikan Sion (Yes. 14:28-32). Selanjutnya sejak tahun 714 SM, raja Hizkia mulai mengupayakan untuk melepaskan diri sepenuhnya dari kekuasaan Asyur. Raja Hizkia agaknya menjajagi koalisi dengan kerajaan Babel namun diperingatkan dengan keras oleh Yesaya (2 Raj. 20:12-19; 39:1-8). Yesaya juga melakukan peringatan yang sama pada saat raja Hizkia dibujuk untuk memberontak melawan Asyur dan berkoalisi dengan kerajaan Mesir dan Etiopia (Yes. 18:1-6; 20:1-6).

\footnotetext{
${ }^{5}$ S. H. Widyapranawa. Tafsiran Alkitab Kitab Yesaya Pasal 1-39 (Jakarta: BPK Gunung Mulia, 2012), 2.

${ }^{6}$ Kerajaan Israel Utara dibawah pimpinan raja Hosea memberontak melawan raja Asyur Salmanesser V, sehingga raja Asyur itu datang menyerang Samaria. Akan tetapi karena kuatnya pertahanan kota Samaria, maka baru tiga tahun kemudian kota itu direbut dan diratakan dengan tanah pada tahun 721 SM oleh pengganti Salmanesser V, raja Sargon II. Kerajaan Israel Utara dengan demikian berakhir (Berthold Anton Pareira, 38).
} 


\section{Pemberitaan Firman Tuhan Nabi Yesaya}

Dalam situasi yang genting antara koalisi Aram-Israel melawan koalisi Asyur-Yehuda, maka Yesaya tampil untuk menyampaikan firman Allah kepada raja Ahas dan menegurnya supaya tidak meminta bantuan Asyur, melainkan tetap tenang dan percaya teguh pada perlindungan Tuhan (Yes. 7:1-9). Konfrontasi Yesaya dengan raja Ahas tersebut menyingkapkan persoalan yang sebenarnya dari kisah ini, yaitu pilihan antara kepercayaan yang teguh kepada Allah atau koalisi yang nekat yang tidak dikehendaki oleh Allah. ${ }^{7}$

Adapun berkaitan dengan rencana penyerbuan koalisi Aram-Israel kepada Yehuda, Yesaya menyampaikan paling sedikit dua hal kepada Ahas, yakni: Pertama, meyakinkan Ahas bahwa rencana-rencana koalisi itu tidak akan berhasil (Yes. 7:3-9). Kedua, Yesaya menantang Ahas untuk meminta sebuah tanda dari Tuhan yang akan menjadi pertanda kegagalan rencana jahat koalisi tersebut (Yes. 7:10-25). Akan tetapi firman Allah yang disampaikan oleh Yesaya ditolak Ahas sehingga ia meminta bantuan kepada Asyur (2 Raj. 16:7; 2 Taw. 28:16). Ahas lebih percaya kepada perlindungan raja Asyur Tiglat Pileser III ketimbang percaya kepada perlindungan Tuhan, Raja semesta alam. Sekalipun sangat kerasnya pendirian Ahas, namun Tuhan tetap memberikan tanda yang jauh lebih indah dari yang dia minta yakni tentang Imanuel, yang menjadi tanda penyertaan Allah (Yes. 7:14). ${ }^{8}$ Tanda ini seharusnya menjadi sesuatu yang berarti bagi Ahas dalam situasi yang menakutkan itu. Ahas dan kerajaan Yehuda sedang terkepung dan sangat mengharapkan pertolongan. Jadi yang dimaksudkan oleh Yesaya adalah bahwa seorang anak akan segera dilahirkan dan sebelum dia cukup umur untuk membedakan antara yang baik dengan yang buruk, keselamatan sudah akan datang. Dengan kata lain yang ditekankan adalah penyertaan dan pertolongan Tuhan. Namun Ahas lebih memilih koalisi dan sikap pro Asyur sekalipun sebenarnya musuhnya yang sesungguhnya bukan Israel atau Aram, melainkan Asyur. Sekalipun dengan sangat tegas, Nabi Yesaya membeberkan kenyataan itu kepadanya, namun hal itu menjadi sia-sia saja. Akibat dari ketidaktaatan

${ }^{7}$ Donald Guthrie. Tafsiran Alkitab Masa Kini 2 (Jakarta: Yayasan Komunikasi Bina Kasih/OMF, 1994), 365.

${ }^{8}$ C. Hassel Bullock. Kitab Nabi-Nabi Perjanjian Lama (Malang: Gandum Mas, 2002), 171.

${ }^{9}$ Terdapat Sarjana yang menyatakan bahwa tanda Imanuel merupakan nubuat mengenai Yesus Kristus yang dilahirkan 700 tahun kemudian, namun dalam konteks tantangan Yesaya terhadap Ahas adalah anak dari Yesaya yang bernama Maher-Syalal Hash-Bas dalam Yesaya 8:1-4. Pandangan ini merupakan pendapat Leon J. Wood. The Prophets of Israel: Nabi-Nabi Israel (Malang: Gandum Mas, 2002), 434. Akan tetapi ada juga sarjana yang menentang bahwa anak dari Yesaya sebagai tanda Imanuel itu sebab istri Yesaya tidak dapat memenuhi syarat sebagai anak dara (C. Hassel Bullock, 184). 
raja Ahas berdampak secara menyeluruh bagi kerajaan Yehuda baik secara politik dan ekonomi (2 Raj. 16:8; 2 Taw. 28:20-21) maupun kerohanian mereka (2 Raj. 16:1-19; 2 Taw. 28:22-25).

Seperti yang telah diungkapkan di atas bahwa Yesaya juga menyampaikan firman Tuhan berupa teguran kepada anak Ahas, raja Hizkia yang sejak tahun 714 SM mengupayakan pemberontakan melawan kerajaan Asyur dengan menjajagi koalisi dengan Babel, Etiopia maupun Mesir. Namun niat Hizkia sudah bulat untuk memberontak terhadap raja Asyur Sargon II (722-705 SM) dengan meminta bantuan Firaun, raja Mesir (2 Raj. 18:21-24; Yes. 36:6, 9). Kembali lagi Tuhan mengutus Yesaya untuk memperingatkan raja Hizkia supaya tidak melakukan koalisi itu sebagai usaha manusia, melainkan tetap percaya teguh pada perlindungan Tuhan (Yes. 30:1-17; 31:1-9). Akan tetapi raja Hizkia menolak firman Tuhan berupa teguran dan nasihat Yesaya, sehingga raja Asyur akhirnya menyerang kerajaan Yehuda dan mengepung kota Yerusalem (2 Raj. 18:13; 2 Taw. 32:1). Kelanjutan pemberontakan raja Hizkia melawan kerajaan Asyur membuat raja Asyur Sanherib (705-681) menyerang kerajaan Yehuda, menghancurkan semua kubu pertahanan Yehuda dan menyebabkan kerajaan itu menjadi kecil dan tidak berdaya (Yes. 22:1-14), sekalipun ibukotanya Yerusalem mendapatkan pertolongan yang ajaib dari "Malaikat Tuhan" (Yes. 36-38; 2 Raj. 19:35). Dengan demikian kerajaan Yehuda berada dalam suasana genting karena serangan kerajaan Asyur yang tadinya merupakan koalisi raja Ahas yang sangat ia andalkan.

\section{Konteks Teologis-Biblika Nubuat Yesaya ${ }^{10}$}

Eksistensi dan Atribut Allah sebagai "Yang Mahakudus, Allah Israel"

Fokus utama dari nubuat Yesaya adalah visinya mengenai Allah sebagai "Yang Mahakudus, Allah Israel" yang dikemukakan dengan hidup dalam panggilan dramatis kenabian Yesaya (pasal 6). Kekudusan Allah mencerminkan perhatian kitab Yesaya terhadap keseriusan dosa

${ }^{10}$ Konteks Teologis Biblika ini tidak bermaksud mengulas keseluruhan mengenai konteks teologis Kitab Yesaya maupun keseluruhan nubuat Yesaya, melainkan akan mengantar kepada makna teologis dari nubuat Yesaya khususnya berkaitan dengan hakikat Allah Israel, penghukuman maupun pengharapan bagi Yehuda dalam pergumulannya menghadapi kerajaan Asyur dan kerajaan-kerajaan lainnya terutama berhadapan dengan Allah mereka, sehingga akan memperoleh gambaran untuk memahami makna teologis dari teks Yesaya 8:23-9:6.

${ }^{11}$ Frasa "Yang Mahakudus, Allah Israel" muncul dua puluh enam kali dalam Kitab Yesaya; dua belas kali dalam pasal 1-39 dan empat belas kali dalam pasal 40-66 (Charles F. Pfeiffer, Everett F. Harrison. The Wycliffe Bible Commentary Volume 2. Malang: Gandum Mas, 2005, 437). 
dan pelanggaran Israel terhadap Allah Yang Mahakudus itu. ${ }^{12}$ Tekanan kepada kekudusan Allah berakar pada pujian kepada kemuliaan Allah di dalam ibadah Bait Suci. Bagi Yesaya, pemuliaan Allah merupakan kesimpulan dari keterbatasan manusia. Kemampuan dan kesombongan manusia akan kekuasaan akan mencelakakan dan mengakibatkan kegagalan. Kehebatan raja-raja dan kerajaan-kerajaan tidak dapat dibandingkan dengan Sang Raja, yakni Tuhan semesta alam (Yes. 6:5). Yesaya adalah juru bicara Allah yang sangat kritis terhadap usaha dari raja-raja Yehuda (baik Ahas maupun Hizkia) untuk memainkan peranan politik dengan mengendalikan nasib sendiri dengan cara manusiawi yaitu berkoalisi dengan kerajaan-kerajaan tertentu. Yesaya juga berkonfrontasi dengan orang-orang bijaksana selaku penasihat raja yang sebenarnya memaksakan keputusan serta menista Yang Mahakudus, Allah Israel (Yes. 5:19, 24). Atas dasar kekudusan Allah itulah, Yesaya mengecam tingkah laku umat Israel, mulai dari para pemimpin mereka (Yes. 5:8-24; 10:1-4). Dengan demikian kekudusan Allah mencakup juga perbedaan hakiki antara Allah; baik kekuatan, kemampuan, kehendak, keputusan dan kemuliaan-Nya dibandingkan dengan kehebatan dan hikmat manusia (raja-raja, penasihat-penasihat raja maupun kemegahan kerajaan dunia).

Berkaitan dengan eksistensi dan atribut Allah sebagai "Yang Mahakudus, Allah Israel", maka tuntutan dasar Yesaya adalah iman kepada Allah seperti penegasan Yesaya terhadap raja Ahas, "Jika kamu tidak percaya sungguh, kamu tidak teguh jaya" (Yes. 7:9). Iman di sini berarti percaya dan lebih bersandar kepada Allah dari pada kekuatannya sendiri. Konteks dari iman ini muncul dari gagasan kerajaan dari keturunan Daud sebagaimana menjadi janji Tuhan melalui nubuat nabi Natan kepada Daud (2 Sam. 7). Janji kepada Daud adalah dasar bagi teologi kerajaan yang dikemukakan dalam kitab Mazmur. Kepercayaan kepada kerajaan berkaitan erat dengan kepercayaan kepada Gunung Sion di Yerusalem, tempat Bait Suci yang dipercaya sebagai tempat tinggal Allah. Adapun teologi kerajaan dan Bait Suci ini merupakan konteks dari iman Yesaya. Yesaya menuntut baik raka maupun rakyat Yehuda hidup dalam iman kepada "Yang Mahakudus, Allah Israel," walaupun hal ini tidak mudah pada saat pasukan kerajaan Asyur sudah mendekat. Yesaya tidak gegabah dengan menyatakan bahwa Allah wajib melindungi umat dari segala marabahaya. Yesaya menyatakan bahwa penderitaan dan penghancuran akan datang, namun ia mendesak supaya hidup berjalan

${ }^{12}$ Andrew E. Hill, John H. Walton. Survei Perjanjian Lama (Malang: Gandum Mas, 2013), 524. 
terus dan tetap percaya kepada Allah yang akan meninggalkan sisa-sisa bangsa itu. $^{13}$

Serangkaian dengan kekudusan Allah, Yesaya juga menekankan keadilan (mishpat) dan kebenaran (tsedaqah). Hal tersebut ditegaskan dalam Yesaya 5:16, "Tetapi TUHAN semesta alam akan ternyata maha tinggi dalam keadilan-Nya dan Allah yang maha kudus akan menyatakan kekudusan-Nya dalam kebenaran-Nya." Keadilan (mishpat) dan kebenaran (tsedaqah) ini juga menjadi dasar dan kokohnya takhta Daud dan kerajaannya seperti yang dinyatakan dalam Yesaya 9:6. Penegasan Yesaya ini menyatakan bahwa kekudusan Allah menyucikan atau mengkhususkan umat-Nya. Kekudusan Allah tersebut harus nyata dalam perbuatan-perbuatan keadilan dan kebenaran. Adapun keadilan, kebenaran dan kekudusan merupakan satu kesatuan dari atribut Allah yang juga harus tampak dalam kehidupan umat yang dikuduskan oleh Allah. ${ }^{14}$

\section{Nubuat Penghukuman dan Janji Pengharapan Masa Depan Israel}

Dengan panjang lebar telah diungkapkan di atas bahwa pelayanan kenabian Yesaya terjadi dalam situasi krisis politik kerajaan Yehuda, kerajaan Israel Utara maupun keberadaan kerajaan-kerajaan di sekitar mereka yang berada dalam situasi konflik akibat ambisi raja-raja mereka. Dalam situasi itulah, Yesaya menyerukan supaya raja dan rakyat Yehuda untuk bersandar dan mengandalkan "Yang Mahakudus, Allah Israel" saja dan bukan kepada kerajaan-kerajaan besar seperti Asyur, Babel, Mesir, dan Etiopia. Pada satu sisi, kerajaan Asyur dipandang sebagai alat Tuhan yang menghukum kejahatan dan kemurtadan Yehuda (Yes. 10:5). Namun pada pihak lain, kerajaan Asyur sendiri karena kesombongannya akan menerima penghukuman Tuhan juga (Yes. 10:7-19, 25-27; 14:24-27; 30:30$33 ; 31: 8)$ serta hal yang sama juga akan terjadi dengan kerajaan-kerajaan lain ${ }^{15}$.

Nubuat mengenai penghukuman ilahi dan janji pengharapan bagi Israel bercampur baur tersebar dalam Kitab Yesaya. Nubuat ini juga disimbolkan dengan nama anak-anak Yesaya sendiri, yakni nama anak yang pertama adalah Maher Syalal Hasy Bas (Yes. 8:1-4), artinya jarahan akan segera datang dan lekas rampung. Maksudnya akan segera terjadi perang dan Israel akan menjadi korban. Sedangkan nama anak yang kedua adalah Syear Yasyub yang berarti sisa yang akan kembali dan bertobat (Yes. 7:3). ${ }^{16}$ Sambil menubuatkan ancaman hukuman yang akan

${ }^{13}$ Dianne Bergant, Robert J. Karris. Tafsir Alkitab Perjanjian Lama (Yogyakarta: Penerbit Kanisius, 2002), 512.

${ }^{14}$ Barnabas Ludji. Pemahaman Dasar Perjanjian Lama 2 (Bandung: Bina Media Informasi, 2009), 73-74.

${ }^{15}$ S.H. Widyapranawa, 3.

${ }^{16}$ Barnabas Ludji, 71-72. 
menimpa bangsa Israel apabila mereka tidak mau bertobat (Yes. 1:21-31; 3:1-4:1), maka Yesaya juga menubuatkan janji keselamatan bagi sisa bangsa Israel yang mau bertobat (Yes. 2:1-5; 4:2-6; 8:23-9:6; 10:20-27; 11:112:6; 25:6-27:13; 29:17-24; 30:18-26; 35:1-10). Hal ini dilukiskan dengan menyanyikan kidung tentang kebun anggur yang jelek (Yes. 5:1-7) maupun kidung tentang kebun anggur yang elok (Yes. 27:2-5). Pada saat bangsa Israel menghasilkan buah anggur asam mereka sangat mengecewakan hati Tuhan (Yes. 5:2-7). Pada saat itu Yesaya menubuatkan ancaman hukuman terhadap mereka, yang mana Tuhan akan menelantarkan mereka seperti kebun anggur yang tidak terawat lagi (Yes. 5:5-6). Sebaliknya pada saat bangsa Israel bertobat, Yesaya menubuatkan pemulihan kembali keadaan mereka, bagaikan kebun anggur yang disirami, dijagai dan disiangi oleh Tuhan sehingga akan menghasilkan buah anggur yang manis (Yes. 27:3-6).

Yesaya juga menubuatkan bahwa Tuhan akan membersihkan kekotoran bangsa Israel (Yes. 4:4) dan akan menumbuhkan tunas baru bagi mereka (Yes. 4:2; 6:13) mulai dari mereka yang tinggal di Sion dan yang tersisa di Yerusalem (Yes. 4:3). Bersama dengan tunas baru tersebut, maka Tuhan akan menebus sisa-sisa umat-Nya (Yes. 11:11, 16) untuk dijadikan umat yang kudus dan setia (Yes. 10:20-22; 28:5-6; 37:3132). Dengan demikian apabila di masa lalu bangsa Israel hanya menghasilkan buah-buah kelaliman dan keonaran (Yes. 5:7), maka di masa depan mereka akan menghasilkan buah-buah keadilan dan kebenaran (Yes. 27:6). Sebagai wujudnya, kota Yerusalem sebagai ibukota kerajaan Yehuda akan seperti dahulu penuh dengan keadilan dan kebenaran (Yes. 1:2l) sehingga akan disebut sebagai "kota keadilan" dan "kota setia" (Yes. 1:26b). Adapun nubuat Yesaya mengenai pemulihan bangsa Israel pasti akan terwujud karena Tuhan akan mengembalikan para hakim dan para penasihat mereka seperti dahulu (Yes. 1:26). Berkaitan dengan kerajaan, sesuai dengan janji Tuhan kepada Daud maka ia akan membangkitkan seorang raja dari keturunan Daud (Yes. 11:1) yang akan mendasarkan dan mengokohkan kerajaan Israel dengan keadilan dan kebenaran untuk selama-lamanya (Yes. 9:6). Maka pada waktu itu, gunung Sion dan kota Yerusalem tempat Bait Suci dan istana raja berada akan menjadi pusat kerajaan damai, tempat segala bangsa mencari kedamaian (Yes. 2:2-4) dan di mana semua ciptaan dapat hidup bersama dengan damai (Yes. 11:6-8) karena tidak ada lagi yang akan berbuat jahat atau berlaku busuk di sana (Yes. 11:9). ${ }^{17}$ Dengan demikian nubuat penghukuman dan janji pengharapan masa depan Israel diperluas dalam cakrawala Kerajaan Allah yang mencakup bangsabangsa dan segenap ciptaan.

\footnotetext{
${ }^{17}$ Hendrik P. Njolah, 40-42.
} 


\section{Eksposisi Yesaya 8:23-9:6}

Komposisi Yesaya 8:23-9:6 ini berada dalam konteks Yesaya 2:2-12:6 yaitu nubuat melawan Yerusalem dan Yehuda yang secara khusus lagi merupakan nubuat tentang Imanuel atau nubuat mesianis. ${ }^{18}$

Yesaya 8:23, "Tetapi tidak selamanya akan ada kesuraman untuk negeri yang terimpit itu. Kalau dahulu TUHAN merendahkan tanah Zebulon dan tanah Naftali, maka di kemudian hari Ia akan memuliakan jalan ke laut, daerah sungai Yordan wilayah bangsa-bangsa lain.

Ayat ini merupakan nubuat pengharapan bagi Israel secara keseluruhan, baik Israel Selatan maupun Israel Utara. Dahulu Tuhan memang merendahkan tanah Zebulon dan tanah Naftali sebagai wilayah dari kerajaan Israel Utara dengan ibukotanya Samaria. Daerah itu telah dirampas oleh raja Asyur Tiglat Pileser III pada perang Suriah-Efraim (734-733). Daerah itu telah dijadikan sebagai propinsi kerajaan Asyur dan penduduknya telah dibuang ke negeri asing (2 Raj.15:29; Yes. 7:2325; 8:21-22). Lagi pula tanah tersebut telah diduduki oleh orang-orang asing yang kafir dari daerah Damsyik ke Barat, ke pantai Laut Tengah. Wilayah itu, juga disebut sebagai "wilayah bangsa-bangsa" yang kemudian dikenal sebagai wilayah Galilea. Di tengah penghukuman yang dialami oleh Israel Utara dan Israel Selatan/Yehuda, Tuhan memberikan janji pengharapan yakni akan memuliakan tanah Zebulon dan Naftali. ${ }^{19}$

Yesaya 9:1-2, "Bangsa yang berjalan di dalam kegelapan telah melihat terang yang besar; mereka yang diam di negeri kekelaman, atasnya terang telah bersinar. Engkau telah menimbulkan banyak sorak-sorak dan sukacita yang besar; mereka telah bersukacita di hadapan-Mu seperti sukacita di waktu panen, seperti orang bersorak-sorak di waktu membagibagi jarahan.

Janji pengharapan akan pemulihan dan keselamatan Israel bukan sekedar sesuatu yang akan diantisipasi pada masa depan, melainkan sesuatu yang pasti terjadi sebagaimana nubuat ini menggunakan dua istilah "telah". Yesaya sedang menyampaikan berita sukacita atau kabar baik bagi bangsa Yehuda dan Israel Utara yang hidup dalam kegelapan besar di negeri kekelaman. Mereka bagaikan orang yang diam dalam "dunia kekelaman", yaitu syeol atau dunia orang mati. Bangsa yang tertindas ini telah melihat terang yang besar yang berasal dari Tuhan

\footnotetext{
${ }^{18}$ Dianne Bergant, Robert J. Karris, 516; C. Hassel Bullock, 182.

${ }^{19}$ Berthold Anton Pareira , 242-243; Dianne Bergant, Robert J. Karris, 521; S.H. Widyapranawa, 51.
} 
sendiri. Terang adalah lambang keselamatan, kebebasan dan kehidupan baru, namun terang juga adalah lambang kemuliaan Allah, kehadiran dan karya-Nya yang menyelamatkan (Mzm. 27:1; 36:10; 56:14). ${ }^{20}$ Karena itu, ayat 1-2 ini merupakan nubuat keselamatan dan sukacita pembebasan bagi Israel yang utuh. Secara khusus dalam ayat 2, nabi Yesaya sedang berbicara dengan Tuhan sebagai penyebab sukacita pembebasan itu. ${ }^{21}$ Kesukaan besar yang dialami oleh seluruh Israel digambarkan sebagai pesta panen yang besar dan pesta kemenangan perang yang gemilang. ${ }^{22}$

Yesaya 9:3-4, "Sebab kuk yang menekannya, dan gandar yang di atas bahunya serta tongkat si penindas telah Kaupatahkan seperti pada hari kekalahan Midian. Sebab setiap sepatu tentara yang berderap-derap dan setiap jubah yang berlumuran darah akan menjadi umpan api.

Kedua ayat di atas merupakan alasan pertama dari nubuat mengenai keselamatan dan sukacita pembebasan yaitu Allah akan membebaskan bangsa itu dari kuk penindasan orang Asyur. Kuk yang berat dan menekan di atas pundak mereka akan dipatahkan dengan cara yang ajaib, "seperti pada hari kekalahan Midian" pada masa Gideon (Hak. 6:9). Dengan mengingatkan mengenai kemenangan atas Midian, maka sebenarnya nabi Yesaya sedang mengingatkan bahwa pembebasan itu benar-benar merupakan karya Tuhan, bukan manusia (Hak. 7:9-15). Sekali lagi dalam ayat 3, nabi Yesaya disebutkan sedang berbicara dengan Tuhan sebagai pembebas dan pemenang. Ayat 4 menjadi hasil dari pembebasan dan kemenangan itu yang "akan" ${ }^{23}$ dialami oleh Israel. Adapun semua perlengkapan perang seperti sepatu tentara yang dipakai untuk maju perang serta jubah perang yang sering berlumuran darah karena pertumpahan darah dalam peperangan akan dibakar habis sebagai tanda berakhirnya perang. ${ }^{24}$ Dengan demikian membawa bangsa Israel untuk mengantisipasi keadaan yang penuh damai sejahtera.

Yesaya 9:5-6, "Sebab seorang anak telah lahir untuk kita, seorang putra telah diberikan untuk kita; lambang pemerintahan ada di atas bahunya, dan namanya disebutkan orang: Penasihat Ajaib, Allah yang Perkasa, Bapa yang Kekal, Raja Damai. Besar kekuasaannya, dan damai sejahtera tidak akan berkesudahan di atas takhta Daud dan di dalam kerajaannya, karena

\footnotetext{
${ }^{20}$ Berthold Anton Pareira, 249-250.

${ }^{21}$ Berthold Anton Pareira, 245-246.

${ }^{22}$ S. H. Widyapranawa, 52.

${ }^{23}$ Sebaiknya istilah "akan" dalam Yesaya 9:1-6 ini dipahami dalam bentuk lampau sebagai "telah" tetapi maknanya adalah di masa yang akan datang. Bentuk lampau ini biasanya merupakan bentuk lampau kenabian/perfectum propheticum (Berthold Anton

${ }^{24}$ S. H. Widyapranawa, 53.
} Pareira, 244). 
ia mendasarkan dan mengokohkannya dengan keadilan dan kebenaran dari sekarang sampai selama- lamanya. Kecemburuan TUHAN semesta alam akan melakukan hal ini.

Adapun alasan berikutnya dari nubuat mengenai keselamatan dan sukacita pembebasan adalah kelahiran seorang anak, pemberian seorang putra bagi bangsa yang masih berdiam dalam kegelapan ini. Siapakah anak itu, tidak nyatakan melainkan hanya diberitahukan mengenai nama yang disandangnya serta lingkup kekuasaannya. Adapun nama yang disandang oleh anak itu dinyatakan sebagai "Penasihat Ajaib" (pele' yo 'es) yang artinya adalah "penasehat yang ajaib", namun sebaiknya diterjemahkan sebagai "Allah Penasehat Ajaib." 25 Hal ini memang didukung oleh pernyataan Yesaya mengenai kebijaksanaan Tuhan, bahwa Dia adalah "ajaib dalam keputusan dan agung dalam kebijaksanaan (Yes. 28:29). Sebutan "Allah yang Perkasa (El-Gibbor) yang artinya adalah "Allah adalah Pahlawan Perang" 26 dan digunakan dalam Yesaya 10:20-21 yang bergandengan dengan TUHAN, Yang Mahakudus, Allah Israel. Adapun sebutan "Bapa yang kekal" (abi'ad') telah digambarkan dalam pembukaan kitab ini (Yes. 2:1-2) yang menyatakan bahwa hubungan Allah dengan Israel seperti hubungan bapak/ayah dan anak-anaknya. Namun istilah ini juga berarti bapak/ayah dari komunitas yang keseluruhan sosial diintegrasikan sebagai suatu keluarga, dan secara khusus untuk perlindungan bagi mereka yang tidak memiliki pelindung/patron, yaitu bagi orang yang miskin, sederhana, seperti yang disebutkan di dalam Yesaya 11:4. Istilah ad berarti kekekalan bukan dalam pengertian sementara, namun kekal yang mengindikasikan kebebasan dari semua keterbatasan. ${ }^{27}$ Sedangkan sebutan "Raja Damai" (sar-shalom) menunjukkan kepada seorang pembebas yang akan mewujudkan nubuat Yesaya pada Yesaya 9:3-4 di atas yang mana Israel telah bebas, aman, damai dari musuh-musuhnya dan juga telah ditegaskan dalam Yesaya 2:2-4. ${ }^{28}$ Kelihatannya Yesaya sedang membandingkan antara Allah sebagai Raja/pemimpin dengan pemimpinpemimpin Israel yang sering dikecam olehnya (Yes. 1:23; 3:4, 11; 30:1-5; 31:1-3).

Ayat 6 ini menyatakan bahwa kekuasaan "anak/putra" tersebut kekal dan diliputi dengan damai sejahtera (shalom) di atas takhta Daud dan dalam kerajaannya karena ia mendasarkan dan mengokohkannya

${ }^{25}$ Aeron Sihombing,. The Biblical Doctrine of Reign of God"; diakses 27 Pebruari 2015, http://aeronsihombing0l.blogspot.com/2014/02/the-biblical-doctrine-of-reign-ofgod.html.

${ }^{26}$ Ibid.
${ }^{27}$ Ibid.
${ }^{28}$ Ibid. 
dengan keadilan (mishpat) dan kebenaran (tsedaqah) yang kekal. Nama yang hebat sebagai sebutan yang dinyatakan dalam ayat 5 segera menegaskan bahwa Tuhan dapat mengubah kekelaman bangsa Israel betapapun gelap akan menjadi terang kembali. Janji ini pasti akan Tuhan sebab Ia sangat prihatin untuk pembebasan dan keselamatan mereka. "Kecemburuan Tuhan" artinya kekuatan kasih-Nya tidak akan membiarkan kekelaman yang menimpa bangsa Israel terus menerus terjadi. $^{29}$

\section{Siapakah Sosok itu?}

Kebanyakan penafsir dan pengkhotbah Kristen dalam rangka pemberitaan yang sifatnya pastoral maupun penginjilan akan segera menghubungkannya dengan Tuhan Yesus Kristus, seperti Berthold Anton Pareira, ${ }^{30}$ Eka Darmaputra, ${ }^{31}$ dan Warren W. Wiersbe. ${ }^{32}$ Teolog yang lain seperti Achim Teschner, ${ }^{33}$ C. Hassel Bullock ${ }^{34}$ dan H. Rothlisberger ${ }^{35}$ menghubungkannya dengan sosok Imanuel dalam Yesaya 7:14 yang menekankan mengenai nubuat sosok Mesias sebagai keturunan Daud dalam Kitab Yesaya kemudian langsung menerapkannya kepada Yesus Kristus dalam terang Perjanjian Baru. Beberapa teolog lain, kendati tidak langsung menghubungkannya dengan Yesus Kristus dalam terang Perjanjian Baru, namun menyatakan bahwa sosok itu adalah Mesias yang adalah keturunan Daud sebagai pengharapan masa depan Israel yang mana harus diantisipasi penggenapan kedatangannya. Nubuat nabi Yesaya ini disebutkan bahwa memiliki perspektif yang lebih jauh dan luas daripada lingkup historis di jaman nabi Yesaya. Pendapat ini menjadi pandangan para teolog yakni Hari Kustono ${ }^{36}$, Harry Mowvley ${ }^{37}$, dan S.M. Siahaan. ${ }^{38}$ Pendapat lain

${ }^{29}$ Berthold Anton Pareira, 254.

${ }^{30}$ Berthold Anton Pareira, 254-256.

${ }^{31}$ Eka Darmaputra. Tatkala Allah Melawat Umat-Nya (Jakarta: BPK Gunung Mulia, 2008), 112.

${ }^{32}$ Warren W. Wiersbe. Nama-Nya Ajaib (Bandung: Kalam Hidup, 2001), 6, dst.

33 Aschim Teschner. Rangkaian Visi Mutiara Kitab Yesaya (Jakarta: Yayasan Komunikasi Bina Kasih/OMF, 2002), 55, dst.

${ }^{34}$ C. Hassel Bullock, 185.

${ }^{35}$ H. Rothlisberger. Firman-Ku Seperti Api: Para Nabi Israel. Jakarta: BPK Gunung Mulia, 2010, 137.

${ }^{36}$ Wahyu Satrio Wibowo. Konsep Mesianis dalam Kitab Yesaya (Yogyakarta: Duta Wacana University Press, 2005), 10.

${ }^{37}$ Mowvley, Harry. Penuntun Ke Dalam Nubuat Perjanjian Lama (Jakarta: BPK Gunung Mulia, 2006), 150.

38 S.M. Siahaan. Pengharapan Mesias Dalam Perjanjian Lama (Jakarta: BPK Gunung Mulia, 2001), 15-19. 
yang agak berbeda adalah pendapat dari Dianne Bergant dan Robert J. Karris yang menyebutkan bahwa sosok itu adalah Raja Hizkia, raja Yehuda anak dari raja Ahas yang sejak tahun 715 memerintah kerajaan Israel Selatan itu. Alasannya adalah berkaitan dengan keprihatinan politik Yesaya bagi kerajaan Israel yang mana sosok itu memiliki kekuasaan yang nyata. ${ }^{39}$

Sebenarnya tidaklah salah untuk menafsirkan dan menerapkan sosok itu kepada Tuhan Yesus Kristus dalam terang Perjanjian Baru sebab para penulis Perjanjian Baru sendiri menyatakan demikian, misalnya Yesus Kristus adalah Imanuel (Mat. 1:23 mengutip Yes. 7:14) dan Dia adalah raja kekal Israel yang akan menduduki takhta Daud (Luk. 1:32-33 mengutip Yes. 9:6). Lagipula kehadiran Yesus sebagai Mesias yang dari Nazaret di Galilea sebagai penggenapan dari pemuliaan Tuhan atas tanah Zebulon dan Naftali (Mat. 4:15-16 mengutip Yes. 8:23) dan Dia juga yang menerangi mereka yang diam dalam kegelapan (Luk. 1:79 mengutip Yes. 9:1). Namun penafsiran Kristologis atas Perjanjian Lama, secara khusus nubuat Yesaya tersebut akan mengaburkan makna teks tersebut bagi pembaca mula-mula kitab Yesaya, pengertian mereka atas nubuat tersebut maupun penerapan teks tersebut dalam situasi pembaca mula-mula.

Pemaknaan terhadap sosok tersebut sebagai Mesias sebagai pengharapan masa depan Israel yang dinantikan namun pada situasi yang melampaui lingkup historis di zaman nabi Yesaya di atas juga tidaklah terlalu salah karena memang benar bahwa merupakan karakteristik kebiasaan Yesaya untuk bergerak bolak-balik antara zaman sejarah dan zaman Mesias. ${ }^{40}$ Namun kembali lagi kepada pembaca mula-mula yakni bangsa Israel bukankah justru akan semakin mengaburkan pengharapan itu sebab sosok Mesias yang dinantikan tidaklah menentu kehadiran-Nya? Padahal nubuat nabi dalam Yesaya 8:23-9:6 begitu terang melukiskan mengenai situasi yang akan (telah) dialami yakni pembebasan, kelepasan, keselamatan yang telah tiba sehingga mereka sangat bersukacita karena telah dibuat Tuhan seperti itu.

Sepertinya penerapan sosok itu kepada raja Hizkia adalah kurang tepat. Karena raja Hizkia juga mengulangi cara ayahnya raja Ahas untuk koalisi dengan Mesir menghadapi kerajaan Asyur. Dengan demikian menyeret dirinya dan kerajaan Yehuda kepada ketidakpercayaan kepada Tuhan. Kemudian raja Hizkia menaklukkan diri kembali kepada raja Asyur dengan membayar upeti berupa perak dan emas yang diambil dari perlengkapan rumah Tuhan dan dari perbendaharaan istana raja (2 Raj. 18:14-16). Kemenangan Raja Hizkia atas raja Asyur Sanherib dan

\footnotetext{
${ }^{39}$ Dianne Bergant, Robert J. Karris, 522-523.

${ }^{40}$ C. Hassel Bullock, 186.
} 
pasukannya juga semata-mata adalah tindakan penyelamatan dari TUHAN di tengah-tengah ketidakberdayaan raja Hizkia (Yes. 37:1-38; 2 Raj. 19; 2 Taw. 32:20-23). Adapun di dalam tradisi Yahudi asli tidak ditemukan konsep keilahian seorang raja sebagaimana yang dinyatakan dalam teks Yesaya 9:5-6 sebagai “Allah Yang Perkasa, Raja Damai!". Akhir hidup raja Hizkia juga mengindikasikan bahwa keangkuhan dirinya membawa kepada penghukuman Tuhan atas kerajaan Yehuda melalui imperium Babel (Yes. 391-8; 2 Raj. 20:12-19; 2 Taw. 32:27-31). Sementara dalam situasi tersebut atas teguran nabi Yesaya, raja Hizkia terkesan menantang nabi Yesaya dengan mementingkan "zona nyaman" dirinya. Teks menyebutkan bahwa Hizkia menjawab kepada Yesaya: "Sungguh baik firman TUHAN yang engkau ucapkan itu!" Tetapi pikirnya: "Asal ada damai dan keamanan seumur hidupku!" (Yes. 39:8). Karena itu pembaca mula-mula Kitab Yesaya 1-39 pasti sudah mengetahui bahwa yang dimaksudkan dengan sosok itu bukanlah raja Hizkia yang mana di akhir pasal 39 dari Kitab Yesaya tersebut ditutup dengan ketidaktaatan raja Hizkia. Dengan demikian mustahil raja Hizkia adalah sosok yang dimaksudkan oleh Yesaya.

Jika demikian siapakah sebenarnya sosok yang diberitakan oleh Yesaya sebagai Sang Penasihat Ajaib, Allah Yang Perkasa, Bapa Yang Kekal, Raja Damai tersebut? Dia mendapatkan kuasa dan kerajaan Daud yang kekal, ia mendasari dan mengokohkan kerajaan itu dengan keadilan (mishpat) dan kebenaran (tsedaqah). Dia mengubah kekelaman bangsa Israel betapapun gelap akan menjadi terang kembali. Dia adalah pembebas dan penyelamat mereka. Dia hadir sebagai realitas "kecemburuan Tuhan" dan yang lebih jelas lagi, sosok itu adalah seorang anak yang dilahirkan, seorang putra yang diberikan!

Menurut penulis, sosok anak yang dilahirkan, seorang putra yang diberikan tetap Tuhan juga, tetapi dibicarakan seolah-olah merupakan sosok yang berbeda dari TUHAN (Yahweh) sebagai "Yang Mahakudus, Allah Israel." ${ }^{42}$ Dengan demikian, saya menafsirkan bahwa Yesaya sedang membandingkan sosok raja-raja Israel Selatan/Yehuda, Israel Utara maupun raja-raja dari kerajaan-kerajaan lain sebagai manusia yang kuat, hebat, dan perkasa tetapi tidak kekal seperti keperkasaan Allah Israel yang mengidentifikasikan diri seperti manusia, bahkan seperti seorang anak yang dilahirkan atau seorang putra yang diberikan. Dalam hal ini Yesaya menggunakan gaya bahasa "antropomorfisme" yaitu Allah yang menyandang atribut manusia dan bukan menggunakan gaya bahasa "teoforis" yaitu manusia yang menyandang atribut Allah. Yesaya juga

\footnotetext{
${ }^{41}$ Gregorius Marlan, Daun Allo. “Identitas Raja Damai Yesaya 8:23-9:7," diakses 17 Maret 2015, http://www.academia.edu/8730376/Identitas_Raja_Damai

${ }^{42}$ Pendapat seperti ini belum pernah diungkapkan dalam buku-buku yang menjadi sumber referensi dalam studi ini (Lihat Daftar Kepustakaan).
} 
sedang memperlihatkan bahwa dalam iman bangsa Israel tidaklah mempertahankan monoteisme murni/tauhid atau kesatuan Allah, hal yang juga nampak dalam seruan para Serafim kudus sebanyak tiga kali terhadap TUHAN dalam penglihatan dan panggilan kenabian Yesaya (Yes. 6:3). ${ }^{43}$

Tidak perlu mengemukakan banyak alasan bahwa sosok yang dimaksudkan Yesaya bagi bangsa Israel maupun pembaca kitabnya mula-mula adalah TUHAN sendiri. Berdasarkan hasil kajian terhadap konteks historis-biblika tentang Nabi Yesaya dan konteks teologisbiblika tentang nubuat Yesaya maupun eksposisi terhadap Yesaya 8:239:6 di atas menunjukkan dengan terang bahwa tetap Tuhan jugalah sosok Sang Penasihat Ajaib, Allah Yang Perkasa, Bapa Yang Kekal, Raja Damai yang menjadi sosok sandaran masa kini (sekalipun dalam konteks penghukuman atas Israel) maupun sosok pengharapan masa depan (janji pemulihan sisa-sisa Israel). ${ }^{44}$ Dengan demikian, maka saya menegaskan bahwa bagi pembaca mula-mula, Tuhan jugalah Sang Imanuel dan Mesias dalam konteks kekinian bangsa Israel sebagai pembaca Kitab Yesaya maupun masa depan eskatologis Israel yang tidak terlepas juga dari konteks kekinian tersebut. Hal ini adalah wajar apabila melihat genre kitab Yesaya sebagai nubuat.

Seperti yang telah diungkapkan di atas, Tuhan jugalah sang Penasihat Ajaib yang melebihi para penasihat raja dan orang-orang bijaksana, keputusan-Nya juga dipenuhi dengan kebijaksanaan. Tuhan juga adalah Allah Yang Perkasa, Sang Pahlawan Perang yang akan menghalau kerajaan-kerajaan penentang Israel seperti Asyur, Mesir, Babel, Etiopia dan lain-lain. Kerajaan-kerajaan ini muncul, termasyur namun kemudian tenggelam namun Israel sekalipun terhimpit dan mengecil tetap hadir sebagai perjanjian Allah terhadap Daud. Tuhan juga adalah Bapa yang Kekal yang mengasihi Israel sebagai anak-anak-Nya yang sekalipun menghukum ketidaktaatan mereka namun berjanji untuk memulihkan mereka. Tuhan juga adalah Raja Damai yang memberikan mereka damai sejahtera tanpa harus bergantung kepada kekuatan rajaraja dan kerajaan-kerajaan manusia yang timbul dan tenggelam. ${ }^{45}$ Hanya

${ }^{43}$ S. H. Widyapranawa, 34.

44 Penafsiran penulis bukanlah bermaksud mengambil jalan tengah antara penafsiran Yudaisme tentang Pengharapan Mesianis maupun penafsiran Kristen secara Kristologis, namun memang genre Kitab Yesaya sebagai nubuat dalam posisi tumpang tindih antara "kekinian" (situasi Israel sebagai pendengar nubuat Yesaya sekaligus pembaca Kitab Yesaya) serta "masa depan" yang merupakan pengharapan eskatologis Israel yang tidak terpisahkan proses tersebut dari situasi kekinian itu juga.

45 Sekalipun terdapat beragam penafsiran mengenai sosok yang dimaksudkan dalam Yesaya 8:23-9:7 seperti yang telah diuraikan dalam dialog di atas, namun berkaitan dengan "Raja Damai", hal yang pasti ialah Allah-lah yang menjadi penjamin Damai itu sendiri. (Lihat Gregorius Marlan,, Daun Allo. “Identitas Raja Damai Yesaya 8:23-9:7"). 
Tuhan juga yang sanggup memberikan dan mendatangkan keadilan (mishpat) dan kebenaran (tsedaqah) bagi Israel.

Bagaimana dengan pengharapan Mesianis masa depan penggenapannya dalam Perjanjian Baru di dalam Yesus Kristus Tuhan? Kembali lagi kita bisa menelusuri bahwa akar-akar inkarnasi begitu kaya dalam Perjanjian Lama, terutama sangat kaya dalam Kitab Yesaya ini. Tuhan dilukiskan sebagai Imanuel, Anak Daud, Penebus, Hamba Tuhan, Mesias dan banyak lagi. Karena itu akar-akar dari Inkarnasi Yesus Kristus sebelum masa Perjanjian Baru masih dapat diusut dalam Perjanjian Lama, khususnya Kitab Yesaya dari pada dicari di luarnya seperti Apokrifa. Hal ini juga berkaitan dengan kesinambungan (kontinuitas) serta kesatuan antara Perjanjian Lama dan Perjanjian Baru. Akan tetapi sebelum memahami Perjanjian Lama dalam terang Perjanjian Baru, sebaiknya kita memahami makna yang tepat sesuai dengan maksud dan berita para penulisnya.

\section{Kesimpulan}

Sepanjang sejarah bangsa Israel (Kerajaan Utara dan Kerajaan Selatan/Yehuda) selalu mengalami dinamika pasang surut. Dosa dan kejahatan para pemimpin mereka ikut menyeret seluruh bangsa itu kepada pemberontakan kepada Allah sekaligus mengakibatkan penghukuman dari Tuhan Yang Mahakudus. Akan tetapi, Allah oleh kekudusan dan anugerah-Nya yang ajaib selalu menyediakan jalan keluar maupun janji pemulihan yang memberikan pengharapan bagi mereka sekalipun hanya sisa-sisa dari bangsa itu yang akan mengalami pembebasan tersebut.

Panggilan dan pelayanan kenabian Yesaya berada dalam situasi genting seperti yang telah diungkapkan di atas. Akan tetapi penekanan nubuat Yesaya adalah kepada eksistensi dan atribut Tuhan Yang Mahakudus yang dapat dipercaya dan diandalkan. Bergantung kepada manusia sekuat atau sehebat apapun kekuasaannya hanya bersifat sementara dan cenderung membahayakan dalam waktu yang lama. Sedangkan bergantung pada Allah justru membawa damai sejahtera dan pemulihan. Dalam situasi genting, sendiri hadir dan bertindak untuk membebaskan dan menyelamatkan bangsa Israel. Tuhan jugalah yang merupakan "Sang Penasihat Ajaib, Allah Yang Perkasa, Bapa Yang Kekal, Raja Damai" yang dapat dipercaya dan diandalkan ketimbang raja-raja, kerajaan-kerajaan maupun orang-orang bijaksana. Bangsa Israel sebagai pendengar nubuat Yesaya maupun pembaca mula-mula Kitab Yesaya telah mendengar hal tersebut, sekalipun mereka "tidak mengerti, tidak menanggapi, tidak mendengar, menutup mata dan tidak melihat" (Yes. 6:9-10). 
Bagi orang Kristen yang memercayai Tuhan Yesus Kristus sebagai Tuhan yang menjadi daging (Yoh. l:14), di samping memiliki kekayaan yang melimpah dalam terang Perjanjian Baru untuk mengenal dan memahami pribadi dan karya Tuhan Yesus Kristus, juga terdapat Perjanjian Lama dengan kekayaan yang sama yakni sebagai kitab untuk menelusuri akar-akar inkarnasi Sang Juruselamat! Karena itu, sebetulnya pemberitaan firman Tuhan dari Yesaya 8:23-9:6 tidak melulu hanya disampaikan pada "musim perayaan Natal," namun menjadi pemberitaan sepanjang masa dalam situasi sukacita terlebih dalam situasi genting. Karena Tuhan begitu mengasihi dan memedulikan setiap situasi manusia dan ciptaan-Nya, bahkan seperti cinta orang muda; dengan "kasih yang cemburu"!

\section{KEPUSTAKAAN}

Alkitab. Terjemahan Baru. Jakarta: Lembaga Alkitab Indonesia, 2009.

Alkitab Edisi Studi. Jakarta: Lembaga Alkitab Indonesia, 2010.

Bergant, Dianne, Robert J. Karris. Tafsir Alkitab Perjanjian Lama. Yogyakarta: Penerbit Kanisius, 2002.

Bullock, C. Hassel. Kitab Nabi-Nabi Perjanjian Lama. Malang: Gandum Mas, 2002.

Darmaputra, Eka. Tatkala Allah Melawat Umat-Nya. Jakarta: Jakarta: BPK Gunung Mulia, 2008.

Green, Joel. B. Memahami Nubuatan. Jakarta: Persekutuan Pembaca Alkitab, 2005.

Greidanus, Sidney. Preaching Christ From The Old Testament. Bandung: Kalam Hidup, 2009.

Guthrie, Donald. Tafsiran Alkitab Masa Kini 2. Jakarta: Yayasan Komunikasi Bina Kasih/OMF, 1994.

Hill, Andrew E, John H. Walton. Survei Perjanjian Lama. Malang; Gandum Mas, 2013.

Ludji, Barnabas. Pemahaman Dasar Perjanjian Lama 2. Bandung: Bina Media Informasi, 2009.

Marlan, Gregorius, Daun Allo. "Identitas Raja Damai Yesaya 8:23-9:7"; diakses 17 Maret 2015, http://www.academia.edu/8730376/Identitas_ Raja_Damai

Marsunu, Seto. Y.M. Suara Ilahi: Pengantar Kitab-Kitab Kenabian. Yogyakarta: Penerbit Kanisius, 2012.

Mowvley, Harry. Penuntun Ke Dalam Nubuat Perjanjian Lama. Jakarta: BPK Gunung Mulia, 2006.

Njolah, Hendrik. P. Mengenal Nabi Yesaya, Nabi Yeremia, Nabi Yehezkiel dan Nabi Amos.Yogyakarta: Yayasan Pustaka Nusatama, 2013. 
Pareira, Berthold Anton. Kritik Sosial Politik Nabi Yesaya. Malang: Penerbit Dioma, 2006.

Pfeiffer, Charles F, Everett F. Harrison. The Wycliffe Bible Commentary Volume 2. Malang: Gandum Mas, 2005.

Rothlisberger, H. firman-Ku Seperti Api: Para Nabi Israel. Jakarta: BPK Gunung Mulia, 2010.

Siahaan, S. M. Pengharapan Mesias Dalam Perjanjian Lama. Jakarta: BPK Gunung Mulia, 2001.

Sihombing, Aeron. "The Biblical Doctrine of Reign of God"; diakses 27 Pebruari 2015; http://aeronsihombing0l.blogspot.com/2014/02/thebiblical-doctrine-of-reign-of-god.html

Singgih, Emanuel Gerrit. Dari Babel ke Yerusalem: Sebuah Tafsir Yesaya Pasal 40-55. Yogyakarta: Penerbit Kanisius, 2014.

Teschner, Aschim. Rangkaian Visi Mutiara Kitab Yesaya. Jakarta: Yayasan Komunikasi Bina Kasih/OMF, 2002.

VanGemeren, Willem A. Penginterpretasian Kitab Para Nabi. Surabaya: Penerbit Momentum, 2007.

Wibowo, Wahyu Satrio. Konsep Mesianis dalam Kitab Yesaya. Yogyakarta: Duta Wacana University Press, 2005.

Widyapranawa, S.H. Tafsiran Alkitab Kitab Yesaya Pasal 1-39. Jakarta: BPK Gunung Mulia, 2012.

Wiersbe, Warren W. Nama-Nya Ajaib. Bandung: Kalam Hidup, 2001.

Wood, Leon J. The Prophets of Israel: Nabi-Nabi Israel. Malang: Gandum Mas, 2002. 